\title{
Embryonic Development of Aplodinotus grunniens (Perciforme: Sciaenidae) in Tenosique, Tabasco, Mexico
}

\author{
Desarrollo Embrionario de Aplodinotus grunniens (Perciforme: \\ Sciaenidae) en Tenosique, Tabasco, México
}

\begin{abstract}
Raúl E. Hernández-Gómez"; Martha A. Perera-Garcia*; Ignacio Valenzuela C.*;
\end{abstract} Temani Duran M.* \& Manuel Mendoza-Carranza**

\begin{abstract}
hernándeZ-Gómez, R. E.; PERERA-GARCiA, M. A.; VAlEnZUELA, C. I.; DURAN, M. T. \& MENDOZACARRANZA, M. Embryonic development of Aplodinotus grunniens (Perciforme: Sciaenidae) in Tenosique, Tabasco, Mexico. Int. J. Morphol., 31(2):633-639, 2013.
\end{abstract}

SUMMARY: The description of the embryonic and larval development was based on 30 eggs and 30 larvae. Breeders were collected on the Usumacinta River, Tabasco, Mexico and were subjected to manual fertilization in May 2011. Fertilized eggs were spherical, pelagic, translucent and non-adhesive and had an average diameter of $1.07 \mathrm{~mm}(\mathrm{SD}=0.10)$, showing a concentric lipid droplet of $0.85 \mathrm{~mm}(\mathrm{SD}=0.02)$. The embryo occupied $100 \%$ of the perivitelline space at hour 14:08 post-fertilization and the egg measured $1.18 \mathrm{~mm}(\mathrm{SD}=0.14)$ at this stage. Eclosion started 17 hours post-fertilization when larvae had a length of $2.54 \mathrm{~mm}(\mathrm{SD}=$ 0.66). Eight preanal and 13 postanal myomeres were observed exhibiting a light brown color. The morphologic characters recorded in this study are similar to the anatomy of embryos and larvae of the Sciaenidae family. The diameter of the eggs and the length of the larvae for A. grunniens are slightly larger than other Sciaenidae species: A. regius, C. striatus, B. chrysora, C. regalis, L. xanthurus, $P$. cromis, G. lineatus and $S$. ocellatus. This is the first study of its kind and its results contribute to the knowledge of the species reproductive biology.

KEY WORDS: Embryo; Drum; Aplodinotus grunniens; Usumacinta.

\section{INTRODUCTION}

Interest for Sciaenidae fish farming has increased in recent years (Jiménez et al., 2005). Several species of this family are already raised in the world: red drum Sciaenops ocellatus (Linnaeus, 1766), Japanese meagre Argyrosomus japonicus (Temminck \& Schlegel, 1843) shi drum Umbrina cirrosa (Linnaeus, 1758) and meagre Argyrsomus regius (Asso, 1801), corvina drum Cilus gilberti (Abbott, 1899), whitemouth croaker Micropogonias furnieri (Desmarest, 1823) and brown meagre Sciaena umbra (Linnaeus, 1758) (Cárdenas, 2010). Aplodinotus grunniens (Rafinesque, 1819) is the only freshwater species of the Sciaenidae family, commonly known as freshwater drum or topuche on the Usumacinta River in Tenosique, Tabasco, Mexico. It features wide geographical distribution in North and Central America (Chao, 2002; Sluss \& Harrel, 2006). Research focuses on its eating habits as well as the effects of its zebra mussel consumption during growth. Other studies have also included the spawning season, as well as monogenean parasitic infection in Lake Erie, Ohio (Daiber, 1952; Deiber, 1953; Mergo \& Crites 1986; French \& Bur, 1996). This fish was first recorded in 1998 at the Rideau River, Ottawa. In addition, research has been conducted on its growth dynamics in Manitoba, Canada, and more recently on its mortality associated to the Viral Hemorrhagic Septicemia (VHS), Type IV, on Lake Ontario (Phelps et al. 1999; Hardisty, 2007; Lumsden et al., 2007). In Mexico, although this species has been rarely researched, it has been studied regarding skin gelatin extraction and characterization in the state of Tamaulipas (Velázquez et al., 2008). In Tabasco a study was conducted on its exploitation in the San Pedro River, Balancán (Castillo et al., 2008). The description of the embryonic development of this fish was mentioned by Davis (1959); however, this information is insufficient. Therefore, this research aims at determining and characterizing the embryonic development of A. grunniens under laboratory conditions with mature specimens from the wild.

*Ingeniería en Acuacultura, División Académica Multidisciplinaria de los Ríos, Universidad Juárez Autónoma de Tabasco, Tenosique, Tabasco, México. **El Colegio de la Frontera Sur Unidad Villahermosa, Ranchería Guineo, sección II CP 86280 Villahermosa, Tabasco, México. 


\section{MATERIAL AND METHOD}

In May 2011, 12 A. grunniens freshwater drum breeders were collected in the El Recreo community $17^{\circ} 28^{\prime} 52^{\prime \prime} \mathrm{N}$ and $91^{\circ} 25^{\prime} 88^{\prime \prime} \mathrm{W}$ from the Usumacinta River in Tenosique, Tabasco, Mexico. A seine net was used with a mesh opening size of $2 \times 2 \mathrm{~cm}, 80 \mathrm{~m}$ long and $3 \mathrm{~m}$ wide. Breeders were previously anesthetized with 2-Phenoxyethanol J.T. Baker, a portion of $0.8 \mathrm{ml}$ per liter of water. The following biometrics were obtained from each specimen: total length with a $60 \mathrm{~cm}$ measuring board and total weight in grams $(\mathrm{g})$ with a Torrey digital scale with a 0.4 accuracy. Sex was determined manually with Pasteur pipettes.

Subsequently, the organisms were treated with sodium chloride baths to 5\% for 30 seconds, and Pfizer oxytetracycline $\mathrm{HCl}$ was applied at a rate of $0.01 \mathrm{ml}$ per 100 $\mathrm{g}$ of body weight to avoid diseases caused by physical stress. Methylene blue was applied topically to treat visible lesions.

Sexual products were manually mixed for fertilization to monitor and characterize the embryonic development. Representative samples of A. grunniens embryos $(n=30)$ were taken periodically in order to record the embryonic development every 3 hours, which were observed in petri dishes for morphometric follow-up. Measurements at this stage were as follows: diameter of the egg, diameter of the vitelline sac, perevitelline space, yolk length, yolk width, and axis of the embryo (Ortiz et al., 2005). The evolution and growth of the embryo was monitored with a Motic BA300 optical microscope fitted with a Digitan Moticam 2300 camera (3.0 megapixels) and the Motic Images Plus $(2.0 \mathrm{~mm})$ measuring software.

Larval development was not determined until the third day of larval survival. The maximum period to observe larval growth was every 24 hours. A total of 30 samples of larvae were analyzed and kept in petri dishes. Some were fixed in $4 \%$ formalin in order to obtain more accurate biometric information such as total length, length of the notochord, head length, diameter of the drop of oil, width of the larvae, diameter of the eye lens, as well as meristic data such as the number of preanal and postanal myomeres (Fuiman, 2002).

Water quality. Parameters recorded during the embryonic development and larval early days were recorded using a Hanna Multiparameter. Averages included dissolved oxygen at $5.58 \mathrm{mg} / \mathrm{l} \mathrm{L}-1(\mathrm{SD}=2.60)$, Ammonium at $0.25 \mathrm{mg} / \mathrm{l} \mathrm{L}-1$ $(\mathrm{SD}=0.15), \mathrm{pH}$ at $8.20(\mathrm{SD}=2.30)$, and temperature at $29.7^{\circ} \mathrm{C}(\mathrm{SD}=4.24)$, which was recorded with a conductivity meter CL35.

\section{RESULTS}

Oocytes and sperm of $A$. grunniens: Mature oocytes were spherical, transparent and slightly yellow and had an average diameter of $0.92 \mathrm{~mm}(\mathrm{SD}=0.29)$ (Fig. 1A). The yolk was homogeneous and no structure was observed on the outer membrane. Sperm of male subjects showed vibrating movements; therefore, only the head was observed and measured, showing an average length of $0.002 \mathrm{~mm}$ (Fig. 1B). Fertilization of the eggs began at 00:33 $\mathrm{h}$ after the sexual products were mixed (Table I).

Characterization of the fertilized egg: Newly fertilized eggs of A. grunniens were spherical, pelagic, translucent and non-adhesive and had an average diameter of $1.07 \mathrm{~mm}$ (SD $=0.10$ ) with only one concentric drop of oil of $0.85 \mathrm{~mm}$ (SD $=0.02)$, a reduced perivitelline space of $0.14 \mathrm{~mm}(\mathrm{SD}=$ 0.05 ) and a smooth envelope.

Embryo division and formation stage: At 00:33 h after fertilization the first cell division occurs and two large blastomeres are observed. At 00:43 $\mathrm{h}$ the second cell division is observed with four blastomeres. Subsequently, at 00:57 h eight blastomeres appear at the animal pole (Fig. 2A). At $1: 12 \mathrm{~h}$ the fourth cell division occurs showing 16 blastomeres (Fig. 2B), while the cells continue to multiply rapidly and at 1:18 $\mathrm{h}$ the fifth division occurs with 32 blastomeres (Fig. 2C). Segmentation continues and the sixth and seventh divisions are observed at 1:33 $\mathrm{h}$ and 2:01 $\mathrm{h}$, respectively (Figs. 2D and 2E). The blastula stage is observed at 2:16 h post-fertilization (Fig. 2F) (Table I).

The gastrulation stage was recorded at $3: 39 \mathrm{~h}$. Subsequently, the blastoderm spread over the yolk where the cell division continued, causing enlargement of the blastodisc (Fig. 2G), without a significant increase in size. This event was recorded at 5:36 $\mathrm{h}$ when a projection sunk in the animal pole was observed in the blastopore (Fig. 2H). The embryonic anlage or layer of undifferentiated cells that originate the development of organs, tissues or determined structures (initial rudimentary trace) was formed at 7:24 h (Fig. 2I).

Neurulation began at 8:03 $\mathrm{h}$, characterized by the formation of the embryonic shield (Fig. 2J) (Table I). The embryo's eye primordium and caudal region formed at 8:38 $h$ post-fertilization. Eggs showed a slight increase with an average diameter of $1.11 \mathrm{~mm}(\mathrm{SD}=0.04)$ and a diameter of the vitelline sac of $0.89 \mathrm{~mm}(\mathrm{SD}=0.18)$, while the perivitelline space was reduced by $0.13 \mathrm{~mm}(\mathrm{SD}=0.02)$ (Fig. 2K). At the beginning of the organogenesis, average embryo axis was $0.95 \mathrm{~mm}(0.04)$ (Fig. 2L). 
HERNÁNDEZ-GóMEZ, R. E.; PERERA-GARCIA, M. A.; VALENZUELA, C. I.; DURAN, M. T. \& MENDOZA-CARRANZA, M. Embryonic development of Aplodinotus grunniens (Perciforme: Sciaenidae) in Tenosique, Tabasco, Mexico. Int. J. Morphol., 31(2):633-639, 2013.

Table I. Duration of the embryonic developmental and larvae stages of A. grunniens.

\begin{tabular}{cl}
\hline Hours:minutes & \multicolumn{1}{c}{ Post-fertilization embryonic developmental stages } \\
\hline $00: 33$ & First division \\
$00: 43$ & Second division \\
$00: 57$ & Third division \\
$01: 12$ & Fourth division \\
$01: 18$ & Fifth division \\
$01: 33$ & Sixth division \\
$02: 01$ & Seventh division \\
$02: 16$ & Blastula \\
$03: 39$ & Gastrula \\
$05: 36$ & Blastodisc enlargement \\
$07: 24$ & Beginning of neurulation \\
$08: 03$ & Embryonic anlage \\
$08: 38$ & Eye primordium and caudal region \\
$10: 09$ & Embryo movements, 68 heart beats per minute \\
13:20 & Increased space between the yolk and the chorion, more visible notochord \\
$14: 08$ & Embryo taking up 100\% of the perivitelline space, embryonic tail developed \\
$16: 45$ & Beginning of eclosion \\
Hours:minutes & Developmental stages after embryo (lar vae) \\
$17: 00$ & Chromatophores are observed, 8 preanal and 13 postanal myomeres \\
$34: 00$ & Mouth starts to form in the larvae, Pectoral fins formed, Pigmented eye. \\
\hline
\end{tabular}

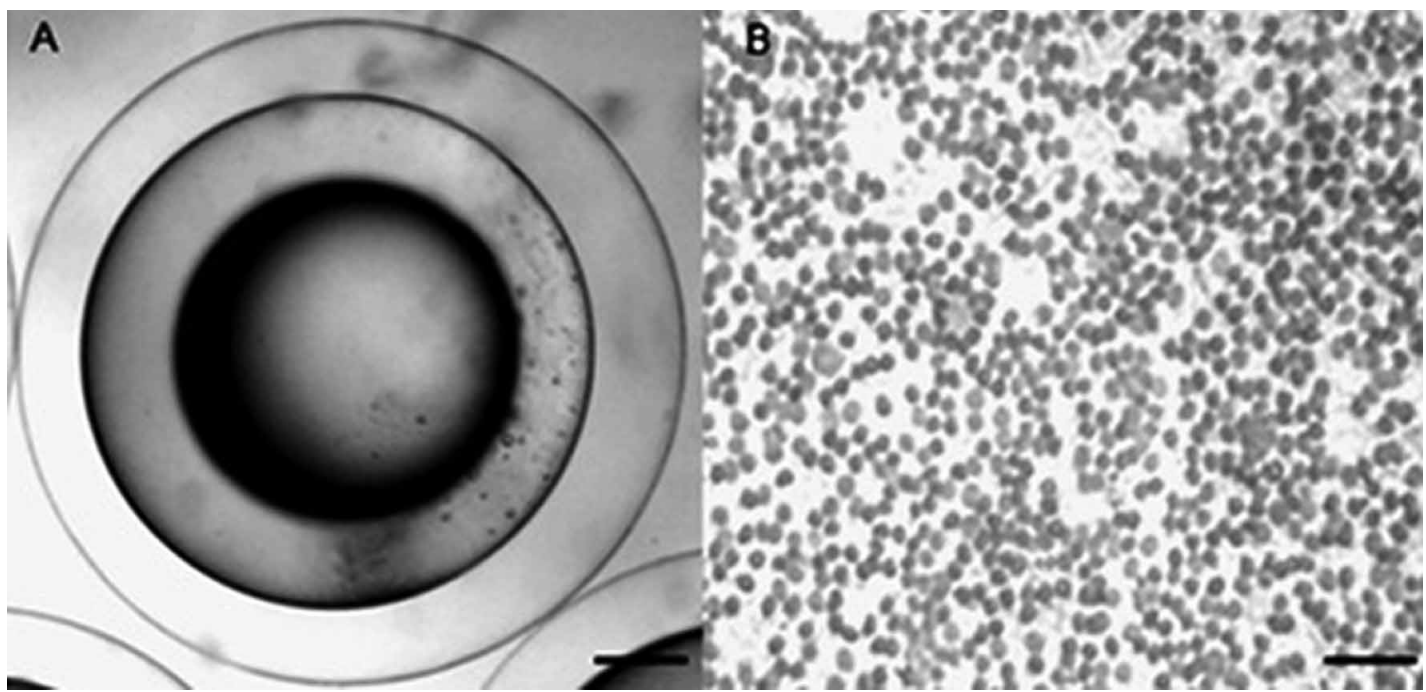

Fig. 1. A) Oocytes of A. grunniens mature females. 4X, scale bar $=0.500 \mathrm{~mm}$. B) A. grunniens sperm. 100X, scale bar $=0.250 \mathrm{~mm}$.

The first body movements of the embryo were observed at 10:09 $\mathrm{h}$ with 68.8 heart beats per minute. At 13:20 $\mathrm{h}$ a slight increase appeared between the yolk and the chorion, and the notochord was more visible. Subsequently, at 14:08 $\mathrm{h}$ the embryo took up $100 \%$ of the perivitelline space with an average diameter of $0.12 \mathrm{~mm}(\mathrm{SD}=0.02)$. At $14: 08 \mathrm{~h}$ postfertilization, the caudal region presented vigorous movements close to the breaking of the shell. At this stage the average 


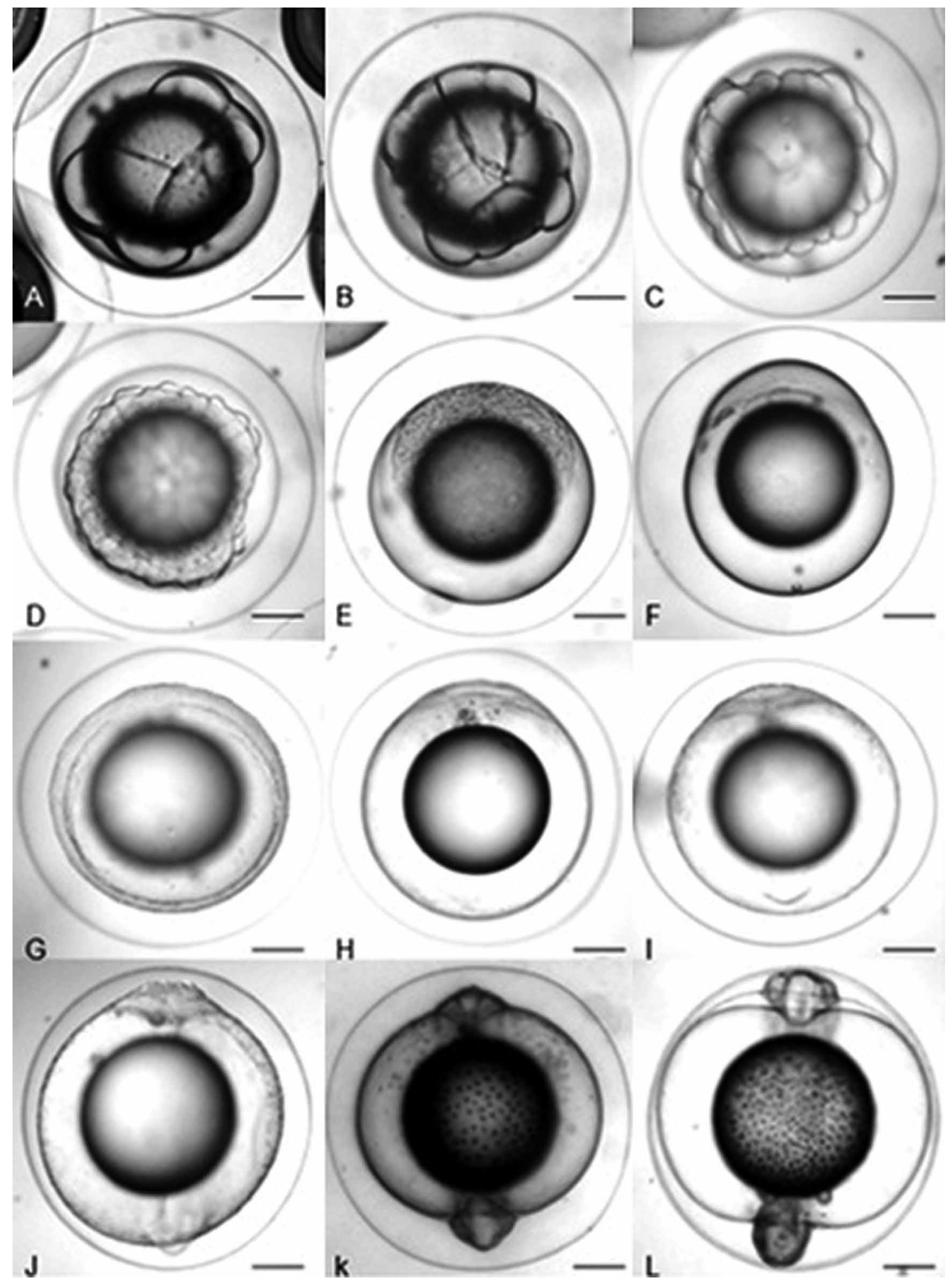

Fig. 2. Embryonic development of Aplodinotus grunniens: A) Third division; B) Fourth division; C) Fifth division; D) Seventh division; F) Blastula; G) Gastrula, blastodisc enlargement; H) Sunk blastopore in the animal pole; I) Embryonic anlage and closure of the blastopore; J) Beginning of neurulation; K) Optic vesicles start to appear; L) caudal region starts to separate from the yolk. 10X, scale bar $=0.5 \mathrm{~mm}$. 


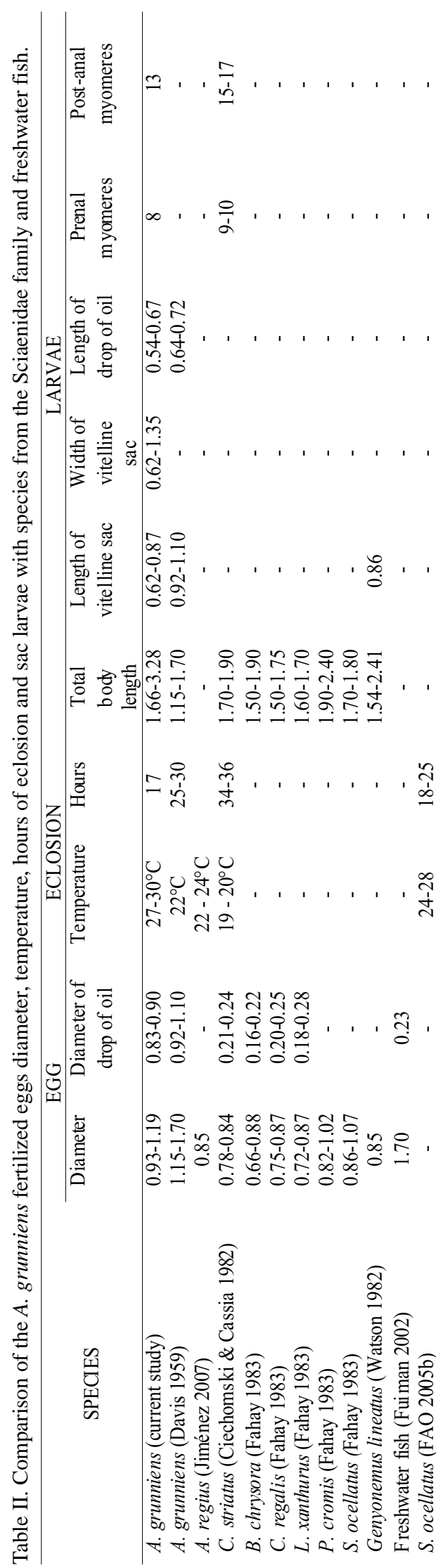

egg diameter was $1.18 \mathrm{~mm}(\mathrm{SD}=0.14)$, the embryo's vitelline sac was $0.94 \mathrm{~mm}(\mathrm{SD}=0.11)$, the drop of oil was $0.58 \mathrm{~mm}(\mathrm{SD}=0.07)$, and the embryo axis had an average length of $1.10 \mathrm{~mm}(\mathrm{SD}=0.04 \mathrm{~mm})$ (Table II).

Pigmentation: The embryo was light brown and the lipid droplet was smooth with small black spots distributed on the surface. As the metamorphosis progressed, the drop showed small black stains around the circumference, as well as irregular star-shaped chromatophores projected from the base of the embryo axis. Small reliefs were observed in the membrane of the vitelline sac in the form of irregular dark colored spots distributed heterogeneously.

Newly hatched larvae: The larvae began to hatch at approximately $17 \mathrm{~h}$ post-fertilization (Table I). They were planktonic and swam with the front facing down, moving with abrupt flow movements caused by undulations of the caudal fin. They were not measured until the third day after hatching because of total mortality during this phase. The larvae had an average length of $2.54 \mathrm{~mm}(\mathrm{SD}=0.66 \mathrm{~mm})$ and average width of $0.88 \mathrm{~mm}(\mathrm{SD}=$ $0.21)$. The notochord length was $2.49 \mathrm{~mm}(\mathrm{SD}=0.65)$ and the average anal and post-anal length was $1.54 \mathrm{~mm}(\mathrm{SD}=0.05)$ and $1.56 \mathrm{~mm}(\mathrm{SD}=0.03)$, respectively. In addition, 8 pre-anal and 13 post-anal myomeres were observed (Table II).

The larvae had a large vitelline sac, sometimes semicircular and other times oval, with an average length of $0.74 \mathrm{~mm}(\mathrm{SD}=0.21 \mathrm{~mm})$ and an average width of $1.08 \mathrm{~mm}(\mathrm{SD}=0.18)$. The drop of oil was approximately $0.59 \mathrm{~mm}(\mathrm{SD}=0.03)$ long and $0.58 \mathrm{~mm}(\mathrm{SD}=0.05 \mathrm{~mm})$ wide. Small spaces with dark tints were observed in the embryonic tail with deployments and displacements called myomeres (Fig. 3, Table II).

Larvae pigmentation: The larvae exhibited the same brown color pattern

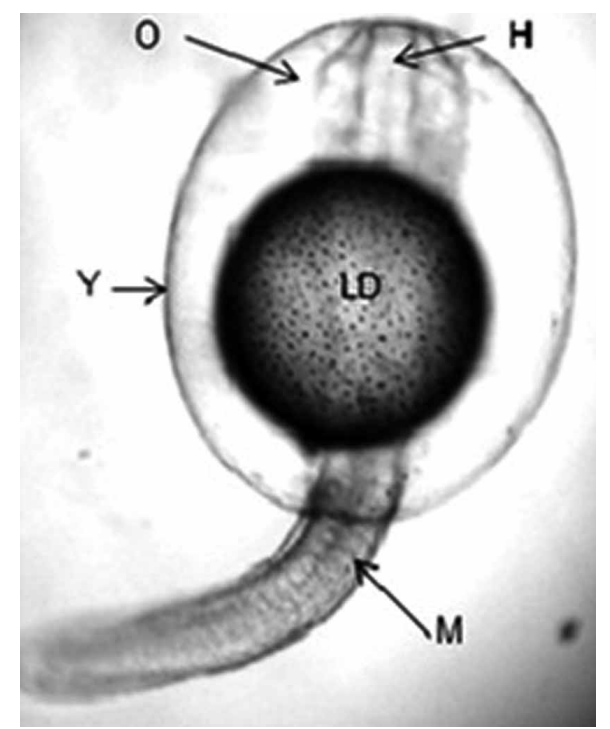

Fig. 3. Newly hatched Aplodinotus grunniens larvae; Optic vesicles (O); Head (H); Yolk (Y); Lipid droplet (LD); Myomeres (M); 10X, scale bar $=0.5 \mathrm{~mm}$. from the embryonic development. A longitudinal arrangement of melanophores was present on the vitelline sac from the lower head region to the middle of the body, starting at the anus. These melanophores extended along the front of the vitelline sac. The yolk had a white to transparent pigmentation, while a dark color was observed in the drop of oil. Five melanophores were observed in the caudal fin of the larvae from the dorsal part to the middle of the body. The margins of the notochord were light brown to transparent while the middle had a white pigmentation. 


\section{DISCUSSION}

This study of the characteristics of the embryonic development of A. grunniens is the first research conducted in the state of Tabasco. However, a previous study conducted in the United States (Lake Erie, Ohio) 52 years ago briefly described morphological and meristic characters and embryo formation period (Davis). There is a distinct difference between the newly hatched $A$. grunniens larvae $(3.28 \mathrm{~mm})$ in the present study and the ones recorded by Davis in 1959, as larvae recorded in that study were $4.20 \mathrm{~mm}$ long, differing approximately $1.02 \mathrm{~mm}$ to those recorded in the present study. These differences in length may be due to the fact that larvae were captured directly from the wild (Lake Erie, U.S.A), and sizes may vary depending on the breeder's diet, health and size as well as environmental conditions. For instance, in the Usumacinta River region A. grunniens larvae are different from Eugerres mexicanus larvae in morphological characteristics and swimming behavior (Hernández et al., 2012), because since birth they swim with the head pointing down.

The morphological characters recorded in this study are similar in anatomy to those of embryos and larvae of teleost fishes, specifically perciformes of the Sciaenidae family (FAO, 2005a, 2005b; Cárdenas). This data agrees with these species of the same family: Argyrosomus regius and Cynoscion striatus (de Ciechomski \& Cassia, 1982; Jiménez et al., 2007).

The diameter of A. grunniens fertilized eggs in this study is similar to the one reported by Davis in 1959 for this same species. In comparison, other Sciaenidae species such as A. regius, C. striatus, Bairdiella chrysora, Cynoscion regalis, Leiostomus xanthurus, Pogonias cromis, Genyonemus lineatus and Sciaenops ocellatus are slightly larger but generally similar in size to freshwater fish (Watson, 1982; Fahay, 1983; Fuiman). A. grunniens fertilized eggs are pelagic, spherical, and floating like other species of the same family and of marine origin, such as meager Argyrosomus regius and the species G. lineatus and C. striatus (striped weakfish). However, they differ in the incubation period (between 34 and 36h) since it is higher than the period recorded in this research $(17 \mathrm{~h})$. They also differ in the incubation period reported by Davis in 1957 for A. grunniens, and for the C. striatus and S. ocellatus species (Ciechomski \& Cassia; Watson; Jiménez et al., 2007; FAO, 2005b) (Table II). During the embryonic development of $A$. grunniens average temperature was $30^{\circ} \mathrm{C}$ under laboratory conditions, which is higher than the one reported for that species in Lake Erie $\left(22^{\circ} \mathrm{C}\right)$, as well as for the incubation period for the C. striatus species in Mar de Plata, Argentina, which was in turn higher than the temperature recorded for the meagre A. regius $\left(22-24^{\circ} \mathrm{C}\right)$ and $S$. ocellatus $\left(24-28^{\circ} \mathrm{C}\right)$ (Davis; Ciechomski \& Cassia; Jiménez et al., 2007; FAO, 2005b).

Comparing morphometric characters of the sac larvae of A. grunniens with other Sciaenidae marine water species, these species $C$. striatus, B. chrysoura, $C$. regalis, $L$. xanthurus, $P$. cromis, $S$. ocellatus, and Genyonemus lineatus are slightly bigger (Ciechomski \& Cassia; Watson; Fahay). The drop of oil was observed at the back of the vitelline sac like in other Sciaenidae larvae; however, it is notably larger in the A. grunniens studied in this research. Unfortunately, size was not compared because no measurements were reported on the research conducted by the other authors (de Ciechomski \& Cassia; Fahay).

This research is the first to be conducted in the region of the rivers of the state of Tabasco, Mexico. It contributes to knowledge about reproductive aspects of the species and offers technical data for captive management of the species in future studies.

\section{ACKNOWLEDGMENTS}

We would like to thank CONACYT and Tabasco Mixed Fund TAB-2009-C18-1202294 for funding this study.

HERNÁNDEZ-GÓMEZ, R. E.; PERERA-GARCIA, M. A.; VALENZUELA, C. I.; DURAN, M. T. \& MENDOZA-CARRANZA, M. Desarrollo embrionario de Aplodinotus grunniens (Perciforme: Sciaenidae) en Tensoque, Tabasco, México. Int. J. Morphol., 31(2):633639, 2013.

RESUMEN: La descripción del desarrollo embrionario y larval se basó en 30 huevos y larvas 30. Los reproductores se recolectaron en el río Usumacinta, Tabasco, México, y se sometieron a la fertilización manual en mayo de 2011. Los huevos fertilizados fueron esféricos, pelágicos, translúcido y no adhesivos presentaron un diámetro promedio de $1.07 \mathrm{~mm}$ $(\mathrm{SD}=0,10)$, mostrando una gota lipidica concéntrica de $0,85 \mathrm{~mm}(\mathrm{SD}=$ $0,02)$. El embrión ocupo el $100 \%$ del espacio perivitelino a las 14:08 horas después de la fertilización y el huevo midió $1,18 \mathrm{~mm}(\mathrm{SD}=0,14)$ en esta etapa. La eclosión comenzó a las 17 horas después de la postfertilización, las larvas presentaron una longitud promedio de $2,54 \mathrm{~mm}(\mathrm{SD}=0,66)$. Se observaron ocho miómeros preanal y 13 postanal exhibieron una coloración marrón. Los caracteres morfológicos registrados en este estudio son similares a la anatomía de los embriones y larvas de la familia Sciaenidae. El diámetro de los huevos y la longitud de las larvas de A. grunniens son ligeramente más grandes que otras especies de Sciaenidae: A. regius, $C$. striatus, B. chrysora, C. regalis, L. xanthurus, P. cromis, G. lineatus y $S$. ocellatus. Este es el primer estudio de su tipo y sus resultados contribuyen al conocimiento de la biología reproductiva de la especie.

PALABRAS CLAVE: Embriones; Tambor; Aplodinotus grunniens; Usumacinta. 


\section{REFERENCES}

Cárdenas, S. Crianza de la corvina Argyrosomus regius. Cuadernos de Acuicultura $n^{\circ}$ 3. Madrid, Fundación OESA, 2010.

Castillo, D. A.; Macías, E. B. \& Valdez, C. E. M. Diagnóstico de la pesca artesanal en el río San Pedro, Balancán, Tabasco. In: Barr, E. E.; Aguila, M. A. C.; Mata, P. F.; Solis, E. G. C.; Gómez, M. P. \& Boa, A. G. (Eds). IV Foro Científico de Pesca Ribereña. Del 9 al 11 de septiembre. Acapulco, INAPESCA, 2008. pp.147-8.

Chao, N. L. Sciaenidae, Croakers (drums). In: Carpenter, K. E. (Ed.). The Living Marine Resources of the Western Central Atlantic. Vol. 2. Rome, Food and Agriculture Organization of the United Nations, 2002. pp.1583-603.

Ciechomski, J. D. \& Cassia, M. C. Observaciones sobre embriones, larvas y juveniles de la pescadilla, Cynoscion striatus. Rev. Invest. Des. Pesq., 3:5-13, 1982.

Daiber, F. C. The food and feeding relationships of freshwater drum, Aplodinotus grunniens, Refinesque in Western Lake Erie. Ohio J. Sci., 52(1):35-46, 1952.

Deiber, F. C. Notes on the spawning population of the freshwater drum (Aplodinotus grunniens Rafinesque) in Western Lake Erie. Amer. Midl. Nat. 50(1):159-71, 1953.

Davis, C. C. A planktonic fish egg from fresh water. Limnol. Oceanogr., 4:352-5, 1959.

Fahay, M. P. Guide to the Early Stages of Marine Fishes occurring in the Western North Atlantic Ocean, Cape Hatteras to the Southern Scotian Shelf. J. Northwest Atl. Fish. Sci., 4:4-419, 1983.

FAO. Cultured Aquatic Species Information Programme, Argyrosomus regius. Cultured Aquatic Species Information Programme, Rome. 2005a. Available in: http://www.fao.org/fishery/culturedspecies/ Argyrosomus_regius/es

FAO. Cultured Aquatic Species Information Programme, Sciaenops ocellatus. Cultured Aquatic Species Information Programme, Rome. 2005b. Available in: http://www.fao.org/fishery/ culturedspecies/Sciaenops_ocellats/en

French, J. R. P. III \& Bur, M. T. The effect of zebra mussel consumption on growth of freshwater drum in Lake Erie. J. Freshwater Ecol., 11(3):283-9, 1996.

Fuiman, L. A. Special considerations of fish eggs and larvae. In: Fuiman, L. A. \& Werner, R. Q. (Eds). Fishery Science, The Unique Contributions of Early life Stage. Oxford, Blackwell Science, 2002. pp.1-32.

Hardisty, C. Growth dynamics of freshwater drum (Aplodinotus grunniens) in Manitoba. Department of Biology, University of Winnipeg. 2007. Available in http://ion.uwinnipeg.ca/ moodie/ Theses/Hardisty2007.pdf

Hernández, R. E.; Perera, M. A.; Castillo, A.; Luna, E.; de la Cruz, J. A.; Gómez, L. M.; et al. Embryonic and larval development of
Eugerres mexicanus (Perciformes: Gerreidae) in Tenosique, Tabasco, Mexico. Rev. Biol. Trop., 60(1):369-79, 2012.

Jiménez, M. T.; Rodríguez de la Rúa, A.; Sánchez, R. \& Cárdenas, S. Atlas de desarrollo de la Corvina Argyrosomus regius (Pisces: Sciaenidae) durante su primer mes de vida. REDVET, VII(1), 2007. Available in: http://www.veterinaria.org/revistas/redvet/ n010107.html

Jiménez, M. T.; Pastor, E.; Grau, A.; Alconchel, J. I.; Sánchez, R. \& Cárdenas, S. Revisión del cultivo de esciénidos en el mundo con especial atención a la corvina Argyrosomus regius (Asso, 1801). Bol. Inst. Esp. Ocean., 21(1-4):169-75, 2005.

Lumsden, J. S.; Morrison, B.; Yason, C.; Russell, S.; Young, K.; Yazdanpanah, A.; et al. Mortality event in freshwater drum Aplodinotus grunniens from Lake Ontario, Canada, associated with viral haemorrhagic septicemia virus, type IV. Dis. Aquat. Organ., 76(2):99-111, 2007.

Mergo, J. \& Crites, J. Prevalence, mean intensity, and relative density of lintaxine cokeri linton 1940 (Monogenea: heteraxinidae) on freshwater drum (Aplodinotus grunniens) in Lake Erie (1984). Ohio J. Sci., 86(3):101-5, 1986.

Ortiz, R. F. A.; Mejía, L. M. \& Acero, P. A. Descripción de los huevos y estadios larvales tempranos del pez rana Antennarius striatus (Shaw, 1794) en estado de cautiverio, con notas sobre su mecanismo de reproducción. Rev. Biol. Mar. Oceanogr., 40(1):23-31, 2005.

Phelps A.; Renaud, C. B. \& Chapleau, F. First record of a freshwater drum, Aplodinotus grunniens in the Rideau River, Ottowa, Ontario. Can. Field-Nat., 114(1):121-5, 2000.

Sluss, A. \& Harrel, S. Aplodinotus grunniens. Animal Diversity. 2006. Available in: http://141.213.176.11/site/accounts/information/ Aplodinotus_grunniens.html

Velázquez de la C., G.; Martínez, T. G.; Hernández, R. V. \& Ramírez, L. J. A. Desarrollo de un proceso de extracción y caracterización de gelatina de la piel de pescado. In: Investigación, Sociedad y Desarrollo, Avances y Perspectivas, Foro Universitario. Tamaulipas, México, Universidad Autónoma de Tamaulipas, 2008. pp.286-9.

Watson, W. Development of eggs and larvae of the white croaker, Genyonemus Lineatus Ayres (Pisces: Sciaenidae), off the Southern California Coast. Fish. Bull., 80:403-17, 1982.

\section{Dirección para Correspondencia:}

Raúl Enrique Hernández Gómez

Profesor Investigador

División Académica Multidisciplinaria de los Ríos

Universidad Juárez Autónoma de Tabasco

Col. Solidaridad S/N Km 1 carretera Tenosique-Estapilla, Tenosique, Tabasco

MÉXICO

Email: raul.hernandez@ujat.mx

Recibido : 06-10-2012

Aceptado: 02-03-2013 